\title{
The Social Constituency of the Jacquerie Revolt of $1358^{*}$ \\ Justine Firnhaber-Baker, University of St Andrews \\ jmfb@st-andrews.ac.uk
}

Named for the sobriquet Jacques Bonhommes given to its participants, the Jacquerie Revolt of 1358 began on the $28^{\text {th }}$ of May in a village called Saint-Leu d'Esserent situated just north of Paris on the Oise River. ${ }^{1}$ Lasting at least until the end of June, it eventually encompassed most of the Ille-deFrance, Picardy, the Vexin, and parts of Normandy and Champagne. Its violence primarily consisted of destroying or stealing nobles' possessions and of attacking noble houses and fortresses, over 100 of which were destroyed or damaged during the revolt. ${ }^{2}$ At least two dozen nobles were killed, but despite the Jacquerie's reputation for violence against women, all but one of the identifiable victims was male and there is almost no evidence of rape. ${ }^{3}$ The revolt was suppressed by a coalition of noblemen, acting in concert with the French and Navarrese crowns, who defeated the rebels in pitched battles at Meaux and Mello and who then rode across the countryside, exacting retribution from those whom they suspected of participation.

The Jacquerie is famous. It is mentioned in school textbooks, popular histories, and specialist works alike. Along with the Florentine Ciompi Revolt of 1378 and the English Rising (or Peasants' Revolt) of 1381, the Jacquerie featured centrally in the spate of works devoted to the phenomenon of medieval rebellion that appeared in the 1970s. ${ }^{4}$ The Ciompi and the English Rising have been extensively studied, for they fit well with the aims of broader national historiography focused on the communal struggles of northern Italy and the role of the common people in English politics. ${ }^{5}$ The Jacquerie, on the other hand, has received less attention, perhaps because the political historiography of France is primarily focused on royal developments, while its strongly annaliste regional histories eschewed bistoire évenémentielle. ${ }^{6}$ The only scholarly monograph devoted to the Jacquerie, Siméon Luce's Histoire de la Jacquerie d'après des documents inédits, is over a century and a half old. ${ }^{7}$ Over the course of the twentieth century, there were a handful of historical articles and 
a literary monograph. ${ }^{8}$ More recently, several articles and at least one doctoral dissertation have appeared. ${ }^{9}$ Still, the Jacquerie remains a very well-known episode about which very little is actually known.

This article is an effort to increase our knowledge by examining what we can and cannot know about the social background of its protagonists. The social attributes of participants is one of the aspects of the movement that has been at least provisionally explored by previous scholarship, primarily because of the kind of sources available. Over 170 letters of royal pardon (lettres de rémission) issued to individuals and communities involved in the Jacquerie and its repression offer detailed portraits of its participants, making identity an attractively accessible avenue of research. In this essay, I examine more of those portraits and do so more deeply than has been previously attempted, and I come to different conclusions than earlier efforts, but I also argue that our interpretations have to be conscious of and constrained by the way those sources shape the information on offer in ways not acknowledged by earlier scholars. What it is possible to know about the men (and at least a few women) who participated in the revolt is largely limited to those individuals whose circumstances were conducive to pardon. While we can learn a surprising amount about the Jacquerie's social composition from these sources, the significant gaps in our knowledge left by their bias toward certain characteristics and constituencies must not only be acknowledged but incorporated centrally into any effort to interpret the revolt.

\section{Reading the Jacques: Scholars and Sources}

Until the publication of Luce's book, knowledge about the Jacquerie and the Jacques had come almost entirely from chronicles, especially that of Jean Froissart. Froissart offered little specific information on who the rebels were beyond that they were "people from the country towns" (villes champestres). ${ }^{10}$ In fact, his most used term for them is just meschans gens (wicked people). He also famously characterized them in one episode as "little, black hicks" (villains noirs et petits). ${ }^{11}$ But Luce, 
who was one of the earliest students of the École des chartes, was able to exploit the hitherto largely unexplored royal archives for new information. He drew especially upon the royal pardons or lettres de rémission, copies of which were preserved in chancery registers. Issued to individuals or communities, the remissions released their recipient from criminal liability for the actions detailed in the letter. They thus offer alternative narratives to the stories provided by Froissart and the other chronicle witnesses for the revolt. ${ }^{12}$ They also provided a wealth of information about who some of these rebels were, where they lived, what they did for a living, how much money they had, and so on.

Over $40 \%$ of these remissions employ a standard formula to talk about what the recipients did:

$\mathrm{N}$ of village $\mathrm{X}$ was with many people of the neighboring countryside (gens du plat pays d'environ) in the noisy terrors (effroiv) that the people of the countryside committed against the realm's nobles, for attacking nobles' fortresses, destroying their goods, setting fires, pillaging them, and killing some of them ${ }^{13}$

This is helpful in its own right for bulk geographic and prosopographic data, but far more interesting are the many dozens of letters that tell individual stories about what the recipients themselves did during the revolt to need a pardon. One for a certain Arnoul Génelon, for example, tell us that he

agreed under fear of death and of losing all his houses and goods to be captain of the village of Catenoy and to ride and accompany its inhabitants for several days in the company of Guillaume Calle, who had been chosen Captain of the people and commune of the Beauvaisis, during which time a few ruffians (desordenea) from the company killed some people, did some pillaging, set some houses on fire, and committed other crimes, while Arnoul was with the company but not at all in agreement with these things in his heart or his will and [he] would gladly have impeded all their wickedness if he had dared. And when they returned from the castle of 
Ermenonville, he left their company and went to Senlis, where he has since comported himself well and honestly, as he says..$^{14}$

The interpretation of these sources poses serious difficulties, given their elaborate exculpatory strategies and massaging of detail, ${ }^{15}$ but pulling together such documents allowed Luce to get beyond the chronicles' largely stereotyped picture of revolting peasants and to write a much more complex and nuanced history of the revolt. His telling highlighted the links between this sudden outbreak of violence in the countryside in May 1358 and a political crisis that had been brewing in Paris since the English capture of the French King Jean II at the Battle of Poitiers in 1356. In the King's absence, his son, the young Dauphin Charles (later Charles V) was nominally in charge, but in fact two factions vied for power: One was dominated by the King's councilors and some of the great nobility with close ties to the royal house of Valois. The other was led by the head of the Paris merchants, a man named Étienne Marcel, and his co-conspirator, Robert le Coq, bishop of Laon, who himself had close ties with King Charles of Navarre, a potential rival to the newly established Valois dynasty. ${ }^{16}$ In the spring of 1358, the Dauphin and his noble allies moved against Marcel and le Coq's faction, blockading river traffic to Paris on the Marne and the Seine Rivers and gathering an army to threaten the city. The Jacquerie, Luce argued, was the peasant response to the threat posed by the Dauphin's incipient army, which would intensify the misery the country people had already suffered in the Hundred Years War and use the castles to facilitate the pillaging of the countryside if they were not first pulled down. ${ }^{17}$ Though hesitant to make a definitive statement about coordination, Luce did venture that the timing of the Jacquerie was awfully convenient for the beleaguered faction in Paris, and he speculated that Étienne Marcel may have had a role in stirring the peasants to action.

Luce's speculations were sharply rebutted by Jules Flammermont in an article published in 1879. Drawing almost exclusively on chronicle accounts, Flammermont judged such a plot "impossible" 
because, as he said, "that would require people capable of thinking, directed by intelligent leaders" (des hommes capable de raisonner, dirigés par des chefs intelligents), but the Jacques were "rude peasants, without education, without instruction, stupified by poverty and drunkenness" (des paysans grossiers, sans éducation, sans instruction, abrutis par la misère et l'ivrognerie). ${ }^{18}$ Such men were, he said, "incapable" of coordinated action. They just hated noblemen, and the revolt was essentially an accidental "explosion" of resentments nourished, he said, for centuries. ${ }^{19}$

Flammermont's article has enjoyed a perhaps surprising amount of traction. ${ }^{20}$ Until very recently, the most cogent challenge to his depiction was a short article by Raymond Cazelles, which approached the problem of the revolt's purpose primarily from the standpoint of social identity. Entitled "La Jacquerie: Fut-il-un-mouvement paysan?", the piece argued that the answer to that question was negative. ${ }^{21}$ Based on the remissions, Cazelles showed that the rebels counted artisans and clerics among their number, and they were closely allied with cities, including Paris but also Amiens, Senlis, and other regional capitals, which were united in open revolt against the French crown. Cazelles thus concluded that rather than a "peasants' movement" (a term he left undefined), the Jacquerie was not only carefully planned with Parisian direction, but actually a concerted effort between the countryside and the cities to realize their own political vision: "a regional structure reduced to only two elements: la ville et le plat pays. ${ }^{, 22}$ In this vision, there was no place for the old, feudal power of the nobility, power made both possible and visible in their castles, which were, therefore, the objects of attack.

Much about how the Jacquerie and its objectives have been understood has thus depended upon who historians think they were. The participants' identity has been a central focus of my own research into the revolt, which has used a relational database to keep track of the individuals mentioned in the sources. In addition to the chronicles and remissions that have been the mainstay of modern research into the revolt, I have also exploited the records of the lawsuits and settlements 
that were the civil sequela of the Jacquerie, as well as a range of heterogeneous documents, including municipal and monastic records, papal dispensations, private letters, and land transactions. ${ }^{23}$ Yet, the total corpus, which numbers nearly 500 documents, certainly does not exhaust the potential sources for the Jacquerie. While it is based upon extensive research at the Archives nationales and Bibliothèque nationale of France and some archives départementales, there undoubtedly remain more sources to be discovered, especially in local archives. Because these archives are incompletely catalogued, finding those sources is a haphazard task, requiring no small amount of serendipity, as well as a time horizon stretching to decades.

While there can be no question of an exhaustive accounting, the data that the collected sources offer are nevertheless considerable. Among over 1500 individual people and communities mentioned in the documents, 488 individuals and 51 communities can be identified as perpetrators or accused perpetrators of the Jacquerie. Another 250 or so other individuals were involved either as the uprising's victims or its suppressors. The corpus also contains 161 individuals associated with Marcel and le Coq's government in Paris and its other urban allies, 38 of whom are also connected with the Jacquerie. About a fifth of the other people in the dataset is connected with either King Charles of Navarre or to the Dauphin, the rest being judicial by-standers of one sort or another: parties to lawsuits long after the fact, relatives of people directly involved, officials executing judgements, and so forth. This corpus is somewhat larger than that identified by Luce and much larger than that used by Cazelles, who primarily drew upon the documents that Luce had published in an appendix to his book. In addition, the use of a database means that the information can be viewed in some ways that were not available to earlier scholars.

These data obviously offer a wealth of information on the rebels, their allies, their victims, and their suppressors. It is nevertheless important to emphasize just how limited their information is. A point of capital importance is that they only include only a fraction of the people involved in 
the Jacquerie. Some chronicle reports of the Jacques' numbers are probably exaggerated -Froissart at one pointed claimed that if all of them were gathered together in one place, they would have numbered over 100,000 - but less hyperbolic assessments of 4,000 Jacques at a particular battle or companies of hundreds of Jacques encountered on the road or attacking a particular manor indicate that the 500 odd participants in my database are only the tip of a much larger iceberg. ${ }^{24}$

Nor would it be wise to assume that that the visible part of that iceberg is representative of its whole. For one thing, the locatable surviving sources are overwhelmingly of secular, royal, and Parisian judicial provenance. This means that clerics, normally under ecclesiastical jurisdiction, and the vast number of people ordinarily subject to seigneurial justice appear only if they successfully appealed to a royal court or were prosecuted by one via extraordinary means and that case came before an organ of the central administration in Paris. ${ }^{25}$ While there are some mentions of seigneurial prosecutions in royal sources, few seigneurial or ecclesiastical court records survive from fourteenth-century France. ${ }^{26}$ Many sources mention executions, either by local judicial authorities or by those participating in the nobles' "Counter-Jacquerie," without giving any information about those thus killed. ${ }^{27}$ Some sources also mention that individuals had fled in fear of retribution or prosecution. ${ }^{28}$ Some of these refugees from justice received remissions, allowing them take up their old lives, but we have no way of knowing how many others permanently absented themselves. ${ }^{29}$ Of the seven fugitives who did procure remission, five of them mention wives and children. Single, less established Jacques may have had less incentive to return and identify themselves to the authorities.

Another important consideration is that the remissions, which make up about $60 \%$ of the sources directly related to the Jacquerie, are biased not only toward those whose favorable situation made flight unattractive but also toward those who could afford to procure one. These things did not 
come cheap, and they often required social connections and some knowledge of how the legal system worked. ${ }^{30}$ That individuals with a certain amount of wealth and savoir faire participated in the Jacquerie does indeed tell us interesting things about the revolt's constituency, as Cazelles was keen to point out. But at a minimum, the fact that wealthy men participated in the Jacquerie does not mean that poor men did not. Nor, as the final section of this essay discusses, does the overwhelming proportion of identifiable male participants mean that women were absent from or unimportant to the revolt.

\section{Leadership: Rural Elites and Organization}

Among those extraordinary individuals who appear in the documents, most scholarship has focused on the most extraordinary among them: the revolt's leaders. This focus is a natural result of the Jacquerie's remarkable degree of organizational and hierarchical leadership. The Jacques had a supreme commander, called the great or general captain of the gens du plat pays, who is referred to by name as Guillaume Calle in three chronicles and five letters of remission, including the one quoted from above. ${ }^{31}$ Under Calle were a circle of "top brass" who helped to coordinate an organization of regional and village captains who had their own subalterns and who were responsible for coordinating the action of local populations in accordance with orders given to them from higher ups. ${ }^{32}$ We can identify 40 such individuals, who hailed from every region of the revolt. The sources offer extensive details for many of these men, partly because they were the kind of people who could afford personalized pardons, and partly because having played an organizational role made one especially culpable in the crown's eyes and therefore especially in need of pardon. ${ }^{33}$ Many of the examples on which Cazelles based his argument were drawn from remissions for these captains.

Many of these leaders were men of substance or even real wealth: We no longer possess the inventory of Calle's possessions made after his execution, but they were apparently nice enough 
to be given to a nobleman named Robert Garvel and extensive enough to make it worth Calle's widow Isabelle (Ysabelle uxoris defuncti Guillaumi Calli) bringing suit against Garvel to get her dowry portion back. ${ }^{34}$ Calle's lieutenant, Germain de Réveillon, who led a contingent of Jacques against the King of Navarre in Calle's absence, was rich indeed, for although he is described in his remission as an bomme de labour, he estimated the damages he sustained from noble reprisals after the Jacquerie at 3,000 moutons, which might have bought him a small palace. ${ }^{35}$ Simon Doublet, captain of some villages in Picardy owned more than one house, as did Arnoul Génelon, whose remission is excerpted above, for he feared losing toutes ses maisons. ${ }^{36}$ A likely member of Calle's "top brass" named Jean Rose had considerable property of his own and was well known (bien connu) in the city of Compiègne. ${ }^{37}$ Like Calle, Rose had a wife, who, like Calle's widow, was savvy enough to petition the crown after his death. Rose also had children (trois petiz, enfanz). ${ }^{38}$ Another family man, Fremy Houdrier, who generously footed the bill for a dinner with the captain of the Jacques and his men, was married to a noblewoman, and he, too, owned multiple houses. ${ }^{39}$ For these men, at least, this was not a revolt of misère.

Nor were these men sans education. Despite the secular provenance of the sources, there are three captains who were clerics or who at least claimed benefit of clergy ${ }^{40}$ Calle himself was literate, for according to one chronicle he wrote and received letters to and from Étienne Marcel, and in letters of remission we find him corresponding in writing (scripsisset) with Jean Rose and the captain of Pont-Saint-Maxence. ${ }^{41}$ In fact, he may have had his own seal. ${ }^{42}$ In contrast to the later English Rising, widespread destruction of legal documents does not seem to have been a feature of the Jacquerie, but there were a few incidents in which litteris atque cartis or other documents were burned. ${ }^{43}$ The captain of a village called Bessancourt and his "councilor" were clearly sensitive to local legal situations. They reminded everyone in the village not to obey the village prévôt (administrator) while they themselves were away hearing orders from Étienne Marcel because of 
a pending jurisdictional dispute with the nuns of Maubuisson, and they also made the local curé promise not to seal anything to the villagers' detriment. ${ }^{44}$

As the evidence of literacy and legal knowledge suggests, a number of the captains had administrative or military experience. The homme de labour Germain de Réveillon was a familiar of Jean, Count of Montfort, whose war over the Duchy of Brittany may have given de Révellion plenty of experience of war, as well as labor. ${ }^{45}$ De Réveillon also served as the tabellion (or notary) of the royal prévotée at Pont-Sainte-Maxence, where in 1350 his name is on a charter benefiting the priory of Saint-Leu d'Esserent, the village in which the Jacquerie began. ${ }^{46}$ Colot d'Uyron and Géraud Sapience, captains in Champagne, were termed homes d'armes in their joint remission, and their loyal service to the crown was invoked in their supplication for pardon. ${ }^{47}$ Both Hue de Sailleville, who held a commission from Étienne Marcel, and Jean le Féron, who led long-distance military expeditions in the Jacquerie, had also served in the royal army. ${ }^{48}$ Philippe Poignant, approached to be captain of four towns in the Beauvaisis, was a royal sergeant and served as guardian of the bishop of Beauvais and the lords of Saint-Denis. ${ }^{49}$ Simon de Berne, seignuerial prévôt for the county of Beaumont-sur-Oise, became the rebels' captain for that territory. ${ }^{50}$ The man whom Simon de Berne helped elect as captain of the lands of Montmorency, Jaquin de Chennevières, served as the seigneurial prévôt of that lordship from 1362-68, an appointment for which he must have possessed significant prior administrative experience. ${ }^{51}$

Like Jean Rose, bien connu in Compiègne, some of these men had close ties to urban centers and were as comfortable in town as in country. Over 20 Jacques, including some of the more important organizational figures, lived in the city of Senlis. ${ }^{52}$ Along with Amiens, Senlis was a major urban bastion of the revolt, and some of the communities with identifiable captains, such as Montataire and Jaux, are better described as towns than as villages. ${ }^{53}$ Some of these men were artisans not farmers, as Cazelles pointed out, or at least bore surnames or sobriquets that might 
indicate an artisanal profession, like Colart le Mannier (the miller), Jean le Feron (the smith or ironmonger), Eudin le Charon (the cartwright), and the nobly-married Frémy Houdrier, "called the butcher" (dit le bouchier). ${ }^{54}$

The role of urban and artisanal participation in the revolt is worth noting, especially because it has parallels in other large-scale "peasant" revolts of the fourteenth century, including the Flemish Maritime Revolt, the English Rising, and the Languedocian Tuchinat. ${ }^{55}$ But these aspects should not overshadow the fact that rural and agricultural connections predominate. Most of the captains led small communities, and 10 of the 40 identifiable leaders received remissions that included formulaic language in the disposition asserting their right to the peaceful collection and storage of their crops and vines: "allow him to collect and store his crops, work and cultivate his lands and vineyards, and take care of his needs and commerce" ( $l i$ laissent cueillir et mettre a sawvete ses biens qui sont ou seront aus champs labourer \& cultivier ses terres \& vignes \& faire ses besoignes \& marchandises).

The revolt's leadership was thus rural, but markedly elite. ${ }^{56}$ These were well-off, well-connected, experienced men with a lot to lose. They confirm the royal chronicler's observation that there were "rich men, burghers, and others" among the revolt's predominantly laboring masses. ${ }^{57}$ We can well imagine that such men could coordinate with Paris and could envisage knocking down castles as a step toward a new social order built around a rural-urban nexus, though it is less clear how such an objective would have squared with de Révellion's seigneurial service or that of Philippe Poingant. Their presence in the revolt makes a lot of sense if we think of them as their communities' natural leaders. While there are a few cases in which the rebel hierarchy seems to have imposed a leader on a community, in most cases the evidence is that captains were chosen by their communities. Élu or electus are the adjectives commonly used. 


\section{The "Rank and File:" Communities and Conflicts}

Among those participants without an identifiable leadership role, it is possible to find some men who fit the same social profile as the captains. A good example is Colin the Clipper who attended a Jacquerie assembly in Champagne: He was a cleric (clericus), likely one in minor orders, but his surname, tonsor in the Latin remission, is not a reference to his haircut. ${ }^{58}$ It may mean that he was a sheep shearer, and his remission includes the formulaic language quoted above for the unmolested collection and storage of crops. Another translation of tonsor, which Luce favored, is "barber" or "barber-surgeon." Such a profession would fit both with his identification as clericus and with the information that he dealt in spices; his possessions included jars of nutmeg, standard medieval materia medica. On the other hand, the sobriquet tonsor may rather be a reference to a reputation for close dealings, for Colin was relatively wealthy. He owned at least 300 livres worth of property, including some land that he had purchased from the local lord and which paid to him the taxes normally owed to her. Colin paid close attention to the news, so when bells rang in the village and he was summoned to an assembly of local villagers, he believed - or at least could later say that he believed - that this assembly was being held in accordance with a recent royal decree authorizing communal self-defense against pillaging soldiers..$^{59}$

Cazelles, whose analysis did not distinguish between the revolt's leaders and participants, argued that such men -- Colin being one of his examples -- were characteristic of the Jacquerie's participants as a whole. Indeed, he claimed that they made up the majorité. Given the constraints of the evidence, particularly the size of the revolt relative to the number of documents issued to individuals and the bias of that documentation toward the well-off and well-connected, any claim about the "majority" of the Jacques is impossible to test, but even on the basis of the evidence we do have, it is not true. Of the 488 individual participants, only $14.8 \%$ were artisans or bore artisanal surnames. That percentage includes people like Colin whose surname might not have been a professional reference or whose profession may have been quite agricultural. Nearly twice that 
many $-28.3 \%$ - had remissions with the formula about harvesting and storing crops, and slightly fewer $(12.3 \%)$ were qualified as laborers (bomme de labour) as had indications of an artisanal profession. While 31 Jacques served as officers of royal, ecclesiastical, seigneurial, or communal administrations, only nine were clerics. Further analysis disaggregating the leaders from the rest reveals instructive differences and similarities (figure 1). While the captains were significantly less likely to be characterized as artisans or hommes de labour as other Jacques, their remissions contain the agricultural formula only somewhat less frequently than those of non-leaders. Yet, a far greater percentage of captains than non-leaders were clerics or held positions as officers. So, while agriculture was important to both the captains and the participants in the Jacquerie, the rank and file were much more likely to be associated with manual professions and the leaders with intellectual or administrative ones.

[Insert figure 1 here]

These observations are based upon the cases for which the sources offer specific details about their lives and social contexts, but for most of the Jacques named in the sources, we do not have this kind of information. On the other hand, the sources usually do indicate the name of the rebel's village of residence or origin. This is no doubt due to the centrality of the village to the revolt's organization, which was based around the network of village captains. This was not an organizational structure constructed ex nibilo, but one which reflected the fundamental importance of the village community to the organization of the countryside. As the author of a thesis on the Jacquerie observed, village communities were the revolt's "units of mobilization." ${ }^{\prime 60}$ Observing how the revolt unfolded, it appears that most Jacques acted with others from their own village community, often alongside family members to judge by surnames, and as noted above, at least 51 villages or towns were implicated in their entirety, most of them receiving remissions on behalf of the community as a whole (les habitans de la ville de N.). As was the case in the earlier Flemish 
Maritime Revolt (1323-28) and later English rebellions, the Jacques were probably drawing upon the usual way that villages raised and organized troops. ${ }^{61}$ That the captain of Jaux had a sub-officer called a dizinier, the title given to a communal watch's commander in charge of 10 men, suggests that the Jacques took over the community's normal watch there. ${ }^{62}$

Yet while Jacquerie's constituency was in one way intensely local, these village-based groups had considerable interactions with people from other villages during the course of the uprising. As in most rural revolts in pre-modern Europe, an important organizational mechanism of the rebellion was regional assemblies at which representatives of multiple villages gathered. ${ }^{63}$ Such assemblies were held at Gonesse north of Paris, at Breteuil in Picardy, Saint-Vrain in Champagne, and ChillyMazarin south of Paris, as well as at other, unspecified places. ${ }^{64}$ The extramural aspect of the revolt is further demonstrated by the fact that most Jacques did not attack targets in their own village; less than $15 \%$ of the Jacques' hometowns were also the sites of attacks from them. As this suggests, for many, perhaps even most rebels, participation in the Jacquerie involved some travelling beyond their village. A villager from Crugny (about 20 kilometers west of Reims), for example, received remission for attacking a castle at Fère, about 17 kilometers away, and the villagers of Chambly were involved in a multi-village attack on the castle of Jouy-sous-Thelle, 32 kilometers away. As in the case of Chambly and as is apparent from the regional assemblies, much of this travelling involved cooperation with people from other villages. Outside of Meaux, for example, six men "all from [the village of] Tourcy," joined forces with eight others, "all from [the village of] Lizy," a settlement about five kilometers distant. ${ }^{65}$

There were also Jacques who travelled far longer distances, often individually or in small groups. For example, one Perrin Baudin, present for the demolition of the castle of Jouy-sous-Thelle, was later caught 55 kilometers away at Val-de-Reuil, where he was attacking a nobleman's valet. ${ }^{66}$ Long travel was also undertaken by Jean le Féron's compagnie, which marched or, more likely, rode from 
Catheux in the Beauvaisis to the castle of Auffay in Normandy, a journey of 117 kilometers as the crow flies. Some of these travelers seem to have played a coordinating role distinct from that of the village captains, moving from community to community, relaying commands and enforcing discipline. Such "outsider" Jacques were important -- or at least available for blame -- in some of those instances in which villagers attacked targets in their own villages. In the Francilian village of Plainville, for example, the inhabitants said that the rebels (les non-nobles) "came to the village" (venuz en la dite ville), where they wished to attack a fortress with the inhabitants' help. ${ }^{67}$ At Épiais in the Vexin, a "great number country people came (vindrent) to the village" and made them destroy a local knight's houses and property. ${ }^{68}$ The knight's own version of the story confirmed that those involved included pluseurs autres de pluseurs villes. The villagers of Vez and their lord in the county of Valois told a similar tale. ${ }^{69}$

These shadowy people, who constitute an almost constant backdrop in the sources, are referred to in only the most general of terms: les non-nobles, ceux qui on l'appellait Jacques Bonbommes (those who were called Jacques Bonhommes), or most often, les gens du plat pays d'environ (people of the countryside nearby). Such terms, usually given with their definite articles, give a sense of an identifiable group, one distinct from the person or group being remitted. Distinctly and definitely non-noble, they were well known or distinguishable enough for some people to have given them a nickname, and they were country-folk (gens du plat pays), who were from "around here" (d'environ), but not actually from "here."

So, if the revolt was, as Froissart said, one of villes champestres, whose constituents were drawn from and organized by pre-existing village structures, the revolt nevertheless wove these village communities into a regional movement whose dynamics both moved these communallyconstituted groups beyond their villages and introduced outsiders into the villages. It is easy to imagine that this interplay of intra- and extramural people and contexts meant conflicts of interest 
and motivation. The frequent claims of duress notable in the sources had exculpatory aims, but we should not discount the considerable evidence they offer of disagreements over targets and strategies, disagreements that took place not only between villagers and outsiders but between proand anti-Jacquerie faction within the villages themselves. ${ }^{70}$

Three issues are particularly prominent: First, there were disagreements over targets. Members of the "rank and file" refused to attack people who were not noble, despite the instructions of their leaders. There are explicit statements to that effect recorded from incidents at Gonesse and Ermenonville, both places where the non-noble targets were personal enemies of the Parisian faction's leaders. ${ }^{71}$ Objections were also made to attacking one's own lord, as in the case of Vez, mentioned above. Indeed, although one chronicler remarked with shock that some Jacques "even attacked their own lords," the Jacquerie is better characterized as an anti-noble revolt than an antiseigneurial one..$^{72} 75 \%$ of the documents identify the revolt's target as les nobles, while I have not found any that mentions "the lords." "73 Indeed, while the great majority of the Jacques' identifiable victims were noble, fewer than half held lordships. A number of lords intervened with the crown to secure remission for their subjects, as for example in the case of sir Gobert de La Bonne, lord of Sainte-Livière, who supplicated the crown to extend its pardon to the village of Sainte-Livière and to his serf (home de corps), one of the very few references to serfdom that I have found in the Jacquerie's sources. ${ }^{74}$

A second area of conflict was over the possession of sufficient authority for the actions undertaken. These incidents are particularly interesting in light of efforts by the revolt's leaders to cloak themselves in royal authority, for example by using a royal officer to make announcements “on our [the Dauphin's] behalf or that of our lord [the King]" or fighting under banners painted with the royal fleur-de-lys. ${ }^{75}$ But while the country-folk might have been susceptible to propaganda and misinformation, they were not homogeneously uncritical. Near Meaux, orders from the 
Jacques' leadership were met with questions about "what power [the leaders] had to do that and whether they were doing it by royal permission or mandate, or otherwise." ${ }^{96}$ In Chambly, upon receiving a summons from Calle, the villagers wrote to the royal bailiff of Senlis to ask whether the summons was legitimate. ${ }^{77}$ Captains, too, feeling themselves under constraint from popular opinion, might question the movement's legal authority. One Picard captain, popularly elected to the position allegedly against his will, reported his objection that "such congregations and assemblies and the making of a regional captain in the realm of France without the authority and license of our lord [King] or us [the Dauphin] cannot rightly be done." ${ }^{.78}$

The third issue, apparently most acute from the leaders' perspective, was the extent and quality of undisciplined violence. One may view with a gimlet eye Arnoul Génelon's claim that he did not approve of the pillage, arson, and murder committed by his men, but many captains gave similar accounts of men whose excesses they could not control. One regional captain remembered how “the locals did many evils in his presence, [although] he was always telling them 'Don't set fires,' and in order to make them stop as soon as possible, 'Wait for another time.' For this they called him a traitor and wanted to cut off his head." ${ }^{, 79}$ Another captain recounted his "great horror at the excesses and outrages that the country-folk did, against his will and which he could not remedy." The leaders' ineffectual efforts to curb the grassroots' thirst for violence appears, too, in the quatre premiers V alois chronicler's account of the Jacques' disastrous encounter with Charles of Navarre near Mello, where Guillaume Calle's suggestion that the Jacques fall back to Paris was met with shouts of refusal and boasts -- which turned out to be wrong -- that they were "strong enough to fight the gentlemen." ${ }^{81}$

\section{Absences and Unknowns: Women in the Jacquerie}

The "tip-of-the-iceberg" Jacques revealed in the documents were thus a diverse and contentious collection of people and communities. Yet there remain thousands, perhaps even tens of 
thousands, of participants about whom we know nothing at all. What we can surmise about the iceberg below the waterline is limited. It is partly made up of "unknown unknowns," people, incidents, and contexts about whose presence or absence nothing can be stated beyond the humble acknowledgement that there are questions we do not even know to ask, even if we had sources to ask them of. But thinking carefully through the disposition of the texts we do have and the contexts in which they were produced can delimit some areas of ignorance. Among these "known unknowns," as I have already indicated, are those Jacques who were too poor or marginal to receive a remission, those who had fled or who were executed in the Counter-Jacquerie, and those who were not usually subject to secular royal jurisdiction. Another group is women.

Of my 488 Jacques, only eleven were female. ${ }^{82}$ The name of the revolt itself -- derived from the nickname Jacques Bonbomme - apparently confirms this masculine bias. ${ }^{83}$ That "Jack revolted without Jill" was among the evidence that Samuel K. Cohn, jr. deployed in demonstrating that women are rarely found among late medieval rebels on the continent and concluding that medieval revolt was a mainly male enterprise. ${ }^{84}$ That women are hard to find is indubitable, but rather than taking their scarcity at face value and returning our attention to what the men were doing, we need to think carefully through the possible reasons for the small numbers of identifiable rebel women in terms of medieval socio-cultural practices, the way those practices shape our sources, and our own interpretative biases. While my discussion here is not primarily a comparative one, any effort to compare qualitatively or quantitatively the role of women in revolt over space and time requires painstaking attention to the disposition of the sources, to the documentary, legal, and linguistic cultures that produced them, as well as to the variations of gendered experience in different historical societies. In the absence of sustained discussion of such considerations, the interpretative force of comparisons on the basis of numbers of women or types of participation is limited. 
As Vincent Challet has argued, one methodological consideration is that women may rarely appear in the sources for medieval French revolts because judicial authorities were less willing to prosecute women. ${ }^{85}$ For a slightly later period, Natalie Zemon Davis noted a similar pattern: "everywhere [in France and England] the sexus imbecillus might be punished less severely. The full weight of the law fell only on the ruling male." 86 This is not to say that all medieval authorities treated all women with greater leniency than all men in all cases, ${ }^{87}$ but rather that the processes that shaped the available sources differed according to time, place, crime, and context. That women appear disproportionately more frequently in documents relating to civil procedures for the Jacquerie, as I discuss below, rather than in the criminal remissions is suggestive of differential patterns of prosecution in this instance. Furthermore, it is vital to recognize that to the extent that women may have participated in the Jacquerie, the strongly gendered nature of their historical society means that they probably did not do so in the same ways that men did, and that this, too, has implications for the availability of sources and our interpretations of them. As Jelle Haemers and Chanelle Delameillieure insightfully observed, sources - and historians -- tend to focus on the physical violence of revolt, a predominantly masculine activity, rather than other forms of contention and resistance more conducive to female participation. ${ }^{88}$

These are salutary reminders that the contexts of our documents' composition shape the information available, and that they do so in gendered ways. As Sylvia Federico observed regarding women in the 1381 English Rising, historians often unconsciously replicate this gendered bias, making women into "an imaginary component of their society: overlooked and ignored by the scholarship, their presence ... is assumed to be unreal." ${ }^{" 89}$ Federico exploited the more extensive documentation for the English Rising to find dozens of cases of female participation and to argue for a more holistic understanding the constituency of the revolt and its motivations, which she characterized as not only "political" in a narrow sense but as "domestic, bodily, sexual, and personal." ${ }^{90}$ My eleven women are probably proportionately similar to the number of women 
Federico identified in the much larger and better documented Rising, and like her women, my "Jacquelines" highlight the multiplicity of possible interpretations for a multifaceted and incompletely documented mass experience.

We might discount five of these eleven women as participants, for they appear in civil lawsuits where they are named as the surviving relatives of a deceased man. Four are widows, one a daughter. ${ }^{91}$ Possibly, they were being held civilly liable for actions they themselves did not commit. But while dismissing the possibility that these women participated in the rebellion is an apparently conservative interpretation, it may be too conservative, or in a way, rather radical. In the case of the only two widows for whom we have further information the minimalist interpretation is certainly unsatisfactory, for while their stake in their late husbands' estate is noted, that statement is immediately followed by the allegation that they and their husbands had "taken from the [claimant's] goods and enriched themselves" to the tune of 200 livres de Paris. ${ }^{92}$ The two widows' part in this "taking" may have occurred after the violent scenes enacted in and around the claimant's manor, when their previous husbands brought home the spoils of rebellion. But whether we classify these women as "rebels" or not depends on whether we privilege as rebellious only acts of immediate violence or whether, as Haemers and Delameillieure argue, related and supporting acts ought to count, too.

The way that the documents identify the other six possible Jacquelines gives further warning against taking the androcentric naming conventions of late medieval France as proof of female inactivity. All six are also identified as the wife or widow of a named man. Among these six is "Jeanne, wife of Nicolas Bonin," accused along with a dozen others of damaging the houses of a noble couple north of Paris. The document, which does not say that this otherwise unknown Nicolas Bonin was dead, characterizes the Jacquerie as undertaken by "many non-noble men and women" (quamplures homines \& mulieres innobiles). ${ }^{93}$ Those accused of attacking the château at Luzarche 
included "the wife [of] Renier du Brueil," but Renier himself does not appear among the other 56 men (and one widow) named in the suit. ${ }^{94}$ There is also a Margot, "previously the wife of the late Perrenet the short," who is listed among the recipients to a remission granted to 30 named inhabitants of two villages in Champagne. ${ }^{95}$ Despite her widowed status, Margot was probably not a legal substitution for her late husband because criminal responsibility was not inherited. In two cases, women were accused of participation in the Jacquerie alongside their husbands: Égide de Longpré, wife of the late Rénault de Peuple, allegedly helped her husband murder a nobleman in their cellar and then let his wife starve to death, though she was later judged innocent. ${ }^{96}$ In another instance, "the wife of Perrin the saddler," was treated as equally culpable as her husband for stealing a horse from a nobleman, who imprisoned them both. ${ }^{97}$ Finally, in a case of a different sort of retribution, we have Tassone, widow ("formerly wife") of Massi de Vaires, who was the victim of raptus (probably rape) by some noblemen taking reprisals for the Jacquerie. ${ }^{98}$

We can read the stories of Tassone, Égide de Longpré, and the wife of Perrin the saddler in a similarly minimalist way to the civil suits in which women seem to be standing in for their late male relatives. But conservative and careful as that move looks, closing off the more active interpretations is actually the more radical one, for it uncritically accepts the sources' collapsing of women's identities and actions into that of their male kin. Such an interpretation assumes - against both logic and evidence - that fourteenth-century sources would treat men and women in a gender-neutral way. Challet and Davis's cautions about the gendered-workings of justice remind us of at least one reason that would not be true. Indeed, twenty-first-century depictions of men and women suggest that any expectation of gender-neutrality is not only anachronistic for the fourteenth century but not even realistic in our own supposedly egalitarian gender regime. The safer and more methodologically robust approach to the appearance of these women in the sources is that of Federico, who advocates "reading all of [their] possibilities," including those which suggest a maximalist interpretation of female involvement. ${ }^{99}$ 
Of course, acknowledging that the gendered nature of the sources' evidence probably conceals women's involvement in the Jacquerie does not tell us much about what might otherwise have been revealed about that participation. While we cannot proceed as if the sources treated men and women the same way, we must also be respectful of their silences. That imperative makes it all the more important not to impose silence on them when they may in fact be speaking. The mandate that mentions mulieres among the rebels is the only explicit inclusion of women in the judicial documents when referring to the rebels in the aggregate. That compares to 10 or 12 examples of the rebels using or being given the masculine sobriquet Jacques. ${ }^{100}$ But the most predominant ways by far of characterizing the constituents of the revolt were gender neutral. The term gens, almost always specifically gens du plat pays, is used in 133 documents; nonnobles/innobiles appears in 66, and villes or communes occurs in 21 . All of these terms could indicate or include women, as well as men, and it is notable that I have found no source that refers to the Jacques specifically as hommes or viri. To quote Federico once more, the safest methodological approach here is "one that assumes, rather than simply doubts, the presence of women."101

That women were present does not mean that they did the same things as their menfolk. That they probably experienced the revolt differently simply makes sense in terms of what we know about the highly-gendered nature of men and women's lives in the later Middle Ages. One of the most visible organizational feature of the revolt was its almost military organization, no doubt learned in service with the royal French army, which had over the last decade made extensive use of the arrière-ban requiring the armed service of the realm's male subjects. ${ }^{102}$ It was the much-derided service of these men that gave rise to the term Jacques Bonbomme in the first place. ${ }^{103}$ If women have sometimes played active roles in modern guerrilla insurgencies, medieval women's roles in warfare were rarer, more circumscribed, and primarily supporting or defensive. ${ }^{104}$ Such "feminine" military activities do appear in two of the narrative accounts of the revolt. The quatre premiers $V$ alois 
chronicle mentions that both women and men (gen₹, femmes ou hommes) in the towns and other locations arranged to feed the Jacques, which it connects narratively with a report that the Countess of Valois also provided food. ${ }^{105}$ Jean de Venette, likely of peasant origin himself, recounted that when noblemen attacked the city of Senlis for its collusion with the Jacques, the male citizens fought in the streets, while the women (mulieres) poured boiling water on the attackers from the windows above. ${ }^{106}$

The Senlisiennes' actions at home -- indeed in their homes -- returns our attention to the home communities, which as I have emphasized, were as much building blocks of the revolt as the network of captains. Jacques who marched out of the village must have left someone to care for livestock and children -- no doubt most of these were women -- and Jacques who marched into the village would have found it as populated by women as by men. We know less about medieval women in rural France than we do about their better researched English counterparts, but it is easily demonstrable that women had a role in the public life of medieval French villages. ${ }^{107}$ In the villages of Saint-Leu d'Esserent and Dompremy, for example, women made up around 15\% of the villagers settling with their lords in connection with rebellious behavior. ${ }^{108}$ But women's most significant contributions to village life were undoubtedly less formal or institutional. As Robert Fossier argued, the French village may have been a predominantly feminine space, heavily marked by women and girls' sociability around wells and kitchen gardens. ${ }^{109}$ In this regard, it is interesting to note that four of the Jacquelines appear in pairs. The wife of Renier du Breuil appear in one document with Perrote, wife of the late Thomas Harare, and the two widows of Vez in another. ${ }^{110}$ In the first case, any connection between the women is unclear, but in the case of the widows of Vez, these women not only remarried other Jacques, they remarried men from the same family, possibly becoming sisters-in-law. 
One last intimation of what the revolt might have meant from a feminine perspective is offered by a remark in Jean de Venette's chronicle that during the revolt, the Jacques and their "countrified wives" were dressed up rather strangely (curiosius vestitentes). ${ }^{111}$ Translators of this passage have interpreted this to mean that they got dressed up in the finery stolen from the nobles, an interpretation which fits with the previous clause of the sentence, which is about thievery. ${ }^{112} \mathrm{It}$ also fits with a few nobles' accounts of the sumptuous fabrics and clothes that they lost in the revolt. One of those accounts is that which records Égide de Longpré's alleged participation in the revolt and mentions clothes and jewels among the property (vestes jocalia et alia mobilia) that she and her husband were supposed to have stolen during the revolt. ${ }^{113}$ Another is that of the Lord of Vez, whose claim implicating two widows went on at length about the beautiful contents of his lost manor, including "beautiful linens, robes (or gowns), jewels" (grant quantite de beau linge, Robes, Joyaulx), silks and furs, as well as gold and silver dishes. ${ }^{114}$

We might discount Jean de Venette's story because the inversion of sartorial norms was one way chroniclers indicated their disapproval of events, ${ }^{115}$ but the reason that they employed this strategy is because clothes played an essential role in demonstrating and maintaining social order. Late medieval sumptuary laws, with their penalties for dressing above one's station, show how important this was to authorities. ${ }^{116}$ In Paris and other northern cities in 1358, the wearing of redand-blue hoods signaled one's support for Étienne Marcel's regime, while in the countryside, when a nobleman was discovered hiding a "striped hood" under his coat, he and his companion were immediately understood to be "gentlemen's spies" and attacked. ${ }^{117}$ Like Wat Tyler's famous (and fatal) over-familiarity with King Richard II at Smithfield in 1381, the violation of social boundaries could be the most explosively subversive acts committed by rebels. ${ }^{118}$ A peasant wife in a lady's gown was no frivolous frippery. Its political and social charge lay exactly in the personal, bodily, and aesthetic experiences of the woman wearing the gown and the woman whose gown was being worn, as well as the men to whom those bodies were tied in affective, legal, and political ways. The 
baroque charges of rape and child murder that Froissart laid against the Jacques are almost entirely unsubstantiated by the judicial sources, ${ }^{119}$ but whether fact or fantasy, they, too, attest to the way that the rebellion could simultaneously violate social, household, and somatic boundaries.

Jean de Venette's remark about the "more strangely dressed" peasants offers a glimpse of how a revolt of the "non-nobles" against "the nobles" might have been experienced from a feminine point of view. Rather than the destruction of castles or the hardiness to face warrior-aristocrats in battle, perhaps it meant the chance to see oneself dressed up like a lady, to feel those silks (so long envied from afar) against one's own skin, to admire one's husband in the dashing garb of the local dandy and to feel similarly admired in return. Rather than adventure on the road with one's compagnons, it meant weaponizing one's wells and cooking pots for the defense of home and hearth while the children played look out and carried messages up staircases and across courtyards. These are not the kinds of acts that produced court records, but they, too, are acts of rebellion and challenges to the social order. ${ }^{120}$

\section{Conclusion}

Understanding the social constituency of the Jacquerie requires coming at the problem from a number of different directions, but there remain many things that are not and cannot be known about the men and women who participated in the revolt. That negative data - the silences, gaps, and blank spots in the sources -- should not be simply discarded or crowded out by the wealth of positive information available. Those absences must be integral to the interpretation of the revolt. They caution against over-interpretation and over-emphasis of what is clearly visible, and they warn against the too-firm denial of some possible aspects of the revolt, like the extent and nature of its violence or the experiences of women, which appear briefly or not at all in the sources. The portrait of the Jacques and Jacquelines that emerges is a broad and variegated picture with some fuzzy edges and many holes. 
Yet, even with this expanded understanding of who the rebels were, we should be more cautious than previous scholarship has been about imputing motive or objectives to the movement on the basis of the participants' social identity. People often act in ways discordant with what observers consider to be their self-interests, and there are an inestimable number of reasons why an individual might have chosen to participate or not. Given the distance in time and the disposition of the sources, many of these motivations, especially those that drove poor people and women, are probably irrecoverable. Nor are individual agency and interests the only issues. The Jacquerie was not a static "thing" that meant something (or some things) over the whole course of the period between the revolt's beginning in May and its final suppression in July. ${ }^{121}$ Interpretations and objectives changed as events unfolded and were remembered later. As the sociologist of revolution Charles Tilly wrote, "people tell different stories about their programs before, during, and after violent episodes, and they often modify these programs in the course of interaction." ${ }^{\prime 22}$ What the data collected here allow is the identification of some of the commonalities of interest and experience that might have encouraged the constitution of a large and organized, if fluid, rural uprising with close ties to urban centers, as well as the gradations of status and diversity of experience that made fragile things of the coalitions forged between city and countryside, between rural communities, and among the innumerable individuals who constituted the rebels of the Jacquerie.

\footnotetext{
* I would like to thank the participants at the European History, 1150-1500 seminar at the Institute of Historical Research in London and at the Peasant Revolt Workshop at CalTech, where I presented earlier versions of this paper. Special thanks to Alice Taylor and to Warren Brown for inviting me to these seminars and to Teofilo Ruiz for his response to the paper at CalTech. I am also grateful to Speculum's anonymous reviewers, whose comments strengthened this work a great deal. This research was supported by a British Arts and Humanities Research Council Early Career
} 
Fellowship (grant reference AH/K006843/1) and a Research Grant from the Carnegie Trust for the Universities of Scotland.

${ }^{1}$ On the naming of the revolt, see Justine Firnhaber-Baker, “The Eponymous Jacquerie: Making Revolt Mean Some Things", in The Routledge History Handbook of Medieval Revolt, ed. idem with Dirk Schoenaers (Abingdon and New York, 2017), 55-75; cf. Vincent Challet, "Peasants' Revolts Memories: Damnatio Memoriae or Hidden Memories", in The Making of Memory in the Middle Ages, ed. Lucie Doležalová (Leiden and Boston, 2010), 399-405.

2 Bettina Bommersbach, 'Gewalt in der Jacquerie von 1358', in Gewalt im politischen Raum. Fallanalysen vom Spätmittelalter bis ins 20. Jahrbundert, ed. Neithard Bulst, Ingrid Gilcher-Holtey, and Heinz-Gerhard Haupt (Frankfurt, 2008), 46-81. The chronicler Jean le Bel estimated that the revolt destroyed 140 castles (Jean le Bel, Chronique de Jean le Bel, ed. J. Viard and E. Déprez, 2 vols. (Paris, 1904-1905), 257), an estimate not out of line with the number of demolished or damaged chateaux, maisons fors, or fortresses locatable in the judicial sources for the revolt, many of which indicate that multiple but non-enumerated structures fell victim.

${ }^{3}$ Douglas Aiton, “'Shame on him who allows them to live:' The Jacquerie of 1358," unpublished $\mathrm{PhD}$ thesis, University of Glasgow (Glasgow, 2007), 180-83. On the trope of sexual violence in chronicler accounts of the Jacquerie, see Marie-Thérèse de Medeiros, Jacques et chroniqueurs: Une étude comparée de récits contemporains relatant la Jacquerie de 1358 (Paris, 1979), 48-50, 63-64. There are two instances of raptus alleged against Jacques: AN JJ 88, no. 1, fol. 1-2r; AN JJ 89, no. 609, fol. $281 \mathrm{v}$.

${ }^{4}$ Michel Mollat and Philippe Wolff, Ongles bleus, Jacques et Ciompi: Les révolutions populaires en Europe aux XIV et XV siècles (Paris, 1970); Guy Fourquin, Les soulèvements populaires au Moyen Agge (Paris, 1972); Rodney H. Hilton, Bond Men Made Free: Medieval Peasant Movements and the English Rising of 1381 (New York, 1973). More recently, see Hugues Neveux, Les révoltes paysannes en Europe (XIV XVII siècle) (Paris, 1997), 103-11, 115-19. As Samuel Cohn pointed out in his book on late medieval social movements, the emphasis on these "big three" revolts in past historiography 
disproportionate to their duration and impact (Samuel K. Cohn, jr., Lust for Liberty: The Politics of Social Revolt in Medieval Europe, 1200-1450: Italy, France, and Flanders (Cambridge, MA, 2006), quote at 2).

5 Patrick Lantschner, “The 'Ciompi Revolution' Constructed: Modern Historians and the Nineteenth-Century Paradigm of Revolution," Annali di Storia di Firenze, 4 (2009): 277-97; Christopher Fletcher, "Rumour, Clamour, Murmur and Rebellion: Public Opinion and its Uses Before and After the Peasants' Revolt (1381)," in La comunidad medieval como esfera pública, ed. H. Rafael Oliva Herrer, Vincent Challet, Jan Dumolyn, and Maria Antonia Carmona Ruiz (Seville, 2014), 193-96.

${ }^{6}$ The Jacquerie makes brief appearances in political biographies, such as Françoise Autrand, Charles V, le Sage (Paris, 1994) and Roland Delachenal, Histoire de Charles V, 5 vols. (Paris, 1909-31), and in Guy Fourquin's annaliste study, Les campagnes de la région parisienne à la fin du Moyen Âge (du milieu du XIII siècle au début du XVT siècle) (Paris, 1964), 231-33 where the Jacquerie is blamed on the long-term weakness of grain prices, an argument criticized with some acerbity in André Leguai, "Les révoltes rurales dans le royaume de France, du milieu du XIV siècle à la fin du XV", $\mathrm{X}^{\mathrm{e}}$, Moyen Age, 4th ser., 88 (1982): 49-76, at 55.

${ }^{7}$ Siméon Luce, Histoire de la Jacquerie d'ápres des documents inédits, new edn. (Paris, 1894 [1859]). Maurice Dommanget, La Jacquerie (Paris, 1971) has merit but is not based on independent research. ${ }^{8}$ Raymond Cazelles, "La Jacquerie: fut-elle un mouvement paysan?," Académie des inscriptions et belles lettres. Comptes rendus, 122 (1978): 654-66; idem, “The Jacquerie," in Rodney H. Hilton and T. H. Aston (eds), The English Rising of 1381 (Cambridge and New York, 1984), 74-83; Pierre Durvin, “Les origines de la Jacquerie à Saint-Leu d'Esserent en 1358," Actes du $101^{\circ}$ congrès national des Sociétés savantes (Lille - 1976) (Paris, 1978), 365-74; de Medeiros, Jacques et chroniqueurs; David Bessen, "The Jacquerie: Class War or Co-opted Rebellion?” Journal of Medieval History, 11 (1985): 43-59; Neithard Bulst, “Jacquerie' und 'Peasants' Revolt' in der französischen und englischen Chronistik," in Geschichtsschreibung und Geschichtsbewußtsein im späten Mittelalter, ed. Hans Patze (Sigmaringen, 1987), 
791-819. There is also a useful account in Jacques d'Avout, Le meurte d'Étienne Marcel, 31 juillet 1358 (Paris, 1960).

${ }^{9}$ Aiton, “'Shame;”" Bommersbach, “Gewalt,"; idem “Violence dans la Jacqeurie de 1358: faire couler à plaisir le sang?" in La Jacquerie: Entre mémoire et oubli 1358-1958-2008, ed. Pierre Rigault and Patrick Toussaint (Amiens, 2012), 73-88; Samuel K. Cohn, jr, "Enigmas of Communication: Jacques, Ciompi and the English" and Justine Firnhaber-Baker, " $A$ son de cloche: The Interpretation of Public Order and Legitimate Authority in Northern France, 1355-1358," both in La comunidad medieval como esfera pública, ed. H. Rafael Oliva Herrer, Vincent Challet, Jan Dumolyn, and Maria Antonia Carmona Ruiz (Seville, 2014), 227-47 and 357-76; Justine Firnhaber-Baker, "Soldiers, Villagers, and Politics: The Role of Mercenaries in the Jacquerie of 1358," in Routiers et mercenaires pendant la guerre de Cent ans, ed. Guilhem Pépin, Françoise Laine, and Frédéric Boutoulle (Bordeaux, 2016), 101-14; eadem, "Eponymous Jacquerie". The Jacquerie also makes important appearances in Cohn, Lust for Liberty.

${ }^{10}$ Jean Froissart, Chroniques de Jean Froissart, ed. Siméon Luce et al., 13 vols. (Paris, 1869-99), 5:99. ${ }^{11}$ Ibid., 5:105.

${ }^{12}$ For Froissart, see also the apparently unique redaction of the chronicle in Chicago, Newberry Library MS F.37, with some incidents not recorded in other witnesses (transcribed at https://www.dhi.ac.uk/onlinefroissart < accessed 23 February 2018> and see Godfried Croenen, “A 'Re-found' Manuscript of Froissart Revisited: Newberry MS F.37,” French Studies Bulletin 31 (2010): 56-60). Other important chronicles include Jean le Bel, Chronique de Jean le Bel, ed. J. Viard and E. Déprez, 2 vols. (Paris, 1904-1905); Jean de Venette, Chronique dite de Jean de Venette, ed. Colette Beaune (Paris, 2011); Chronique des règnes de Jean II et Charles V: Les grandes chroniques de France, ed. R. Delachenal, 3 vols. (Paris, 1910-20); Chronique des quatre premiers V alois (1327-1393), ed. Siméon Luce (Paris, 1862); Chronique normande du XIV siècle, ed. Auguste Molinier and Émile Molinier (Paris, 1882); Chronographia regum francorum, ed. H. Moranvillé, 3 vols. (Paris, 1891-97); Chronique de Richard Lescot, religieux de Saint-Denis (1328-1344), suivie de la continuation de cette chronique 
(1344-1364), ed. Jean Lemoine (Paris, 1896). There are also accounts in The Anonimalle Chronicle, 1333 to 1381, from a MS. written at St Mary's Abbey, York, ed. V. H. Galbraith (Manchester, 1970), Thomas Gray, Scalachronica: The Reigns of Edward I, Edward II and Edward III, ed. and trans. Herbert Maxwell (Felinfach, 2000 [1907]), and Matteo Villani, Cronica: con la continuazione di Filippo Villani, ed. Giuseppe Porta, 2 vols. (Parma, 1995). On the relationships and dependencies among chronicles, see de Medieros, Jacques et chroniqueurs.

13 “este avec pluseurs autres du pais d'environ aus effroiz qui derrereinement \& nagaires ont este faiz par les genz du dit plait pais contre les nobles du dit Royaume a abatre en pluseurs lieux forteresses dissiper leur biens y mettre les feux les pillier \& aucuns mis a mort" (this example from Paris, Archives nationales [hereafter AN] JJ 86, no. 326, fol. 109v).

14 “par la force \& contrainte de feu Guillaume Calle nagaires esleu Capitaine du pueple \& commun de Beauvoisiz ... Arnoul Guenelon de Castonoy pour paour de mourir \& de perdre toutes ses maisons \& autres biens se feust consent d'estre Capitaine de la dite ville de Castenoy et de Chevauchier \& aler avecues les habitanz dicelle par aucunes journees en la compaignie des diz Guillaume Calle \& de ses adherens ou quell temps par aucuns desordenez de la dite compaignie furent plusieurs personnes mises a mort plusieurs pillages arsines de maisons et plusieurs autres maux faiz lui estanz en la dite compagnie sanz ce que ycelui Arnoul en feust oncques consentans en cuer ny en volente mais eust volentiers empesche tout leur male voulente se il eust ose Et au Retourner qu'il firent du chastel d'Ermonville s'en departi et s'en ala hors de leur compaignie mettre en la ville de Senliz ou il s'est depuis bien portez \& loyaulment si comme il dit a la defense dicelle contre les ennemis du Royaume de France” (AN JJ 86, no. 391, fol. 136r).

${ }^{15}$ See Natalie Zemon Davis, Fiction in the Archives: Pardon Tales and their Tellers in Sixteenth-Century France (Stanford, 1987); Claude Gauvard, "De grace especial:" Crime, état et société en France à la fin du Moyen Age, 2 vols. (Paris, 1991), 1:64-68; and Peter Arnade and Walter Prevenier, Honour, Vengeance, and Social Trouble: Pardon Letters in the Burgundian Low Countries (Ithaca, NY, 2015), esp. 4-6. 
${ }^{16}$ For these events see Delachenal, Histoire de Charles V, 1:227-383; d'Avout, Le meurte d'Étienne Marcel; Autrand, Charles V, ch. 10-14; Jonathan Sumption, The Hundred Years War, 4 vols. to date (Philadelphia and London, 1990-2015), 2:ch. 5-7.

${ }^{17}$ In fact, Luce was wrong about the desperate state of the peasantry; the epicenter of the Jacquerie in the Beauvaisis was one of the only areas that had not been subject of recent military ravages. (Delachenal, Histoire de Charles V, 1:398; Firnhaber-Baker, "Soldiers, Villagers, and Politics.”).

${ }^{18}$ Jules Flammermont, "La Jacquerie en Beauvaisis," Revue historique, 9 (1879): 123-43, at 127. ${ }^{19}$ Ibid., 129.

${ }^{20}$ On the development of Jacquerie historiography, see Bessen, “The Jacquerie," 44-46 and the comments of Samuel K. Cohn, jr. (ed. and trans.), Popular Protest in Late Medieval Europe: Italy, France and Flanders (Manchester, 2004), 149-50.

${ }^{21}$ Cf. Neveux, Les révoltes paysannes, 37.

${ }^{22}$ Cazelles, "La Jacquerie," 665-66.

${ }^{23}$ Criminal prosecutions were forbidden as a consequence of the blanket remission the Dauphin issued in August 1358 (AN JJ 86, no. 241, fol. 80, ed. Luce, Histoire, no. 23). This general remission's order that “toutes rencunes \& disscencions, toute voie \& poursuite criminele cessaissent" (AN JJ 90, no. 564, fol. 279r) was usually noted in the remission issued to individuals and communities. There is one case that appears in a criminal register of the Parlement (AN X2a 7, fol. 213r), but it may have been accidentally copied into the wrong register, for it records permission to settle the civil claims and mentions no criminal processes or penalties.

24 "Meismement li rois de Navare en mist I jour a fin plus de III M assés priés de Clermont en Biauvesis, mais il estoient ja tant montepliiet que, se il fuissent tout ensamble, il euissent bien esté C M hommez" (Newberry Library MS F.37, fol. 168r, see n. 12, above, for this redaction of Froissart's chronicle); 4,000: Chronique des quatre premiers Valois, ed. Luce, 73; 600: AN JJ 109, no. 434, fol. 214; 400 at the manors of Jean de Charny: AN X1a 14, fol. 391, ed. Luce, Histoire, no. 55. 
${ }^{25}$ For the relationship between justice within and outside the royal domain, see Ferdinand Lot and Robert Fawtier, Histoire des institutions françaises au Moyen Agge, 3 vols. (Paris, 1957), 2:154-56 and Bernard Guenée, Tribunaux et gens de justice dans le bailliage de Senlis à la fin du Moyen Age (vers 1380 vers 1550) (Strasbourg, 1963), 64-67. The provincial court records of the royal baillis are extremely fragmentary for the fourteenth century.

${ }^{26} 51$ remissions mention seigneurial jurisdiction, of which 21 include language enabling seigneurial remission, such as: "en ampliant nostre dite grace nous voulons \& occtroions au dit seigneur de Montmorenci que il ou ses genz pour luy ... leur puisse faire semblable grace sanz ce qu'il tourne a luy ne a sa jurisdiction prejudice" (AN JJ 90, no. 419, fol. 211). Charles V claimed remission as a sovereign prerogative in 1372 , so seigneurial efforts at imitation were a fraught subject: Pierre Flandin-Bléty, "Lettres de rémission des vicomtes de Turenne aux $\mathrm{XIV}^{\mathrm{e}}$ et $\mathrm{XV}^{\mathrm{e}}$ siècles," Mémoires de la Société pour l'bistoire du droit et des institutions des anciens pays bourguignons, comtois et romands, 45 (1988): 125-43; Gauvard, "De grace especial”, 2:895-96.

${ }^{27}$ For example, in Caen "des gens de Picardie qui furent mis à mort et perilliez sur le marchié de la dite ville" (AN JJ 87, no. 321, fol. 204v-205, partially ed. Luce, Histoire, no. 45). The term "Counter-Jacquerie" is a coinage of Luce, Histoire.

${ }^{28}$ A remission for the champenois village Heiltz-le-Marrupt, for example, mentions that those most responsible for the disturbances "se sont renduz futtiz et absentez du païs" (AN JJ 86, no. 357, fol. 122, ed. Luce, Histoire, no. 31).

${ }^{29}$ Remitted fugitives at AN JJ 86, no. 231, fol. 75v-76r, ed. Luce, Histoire, no. 30; AN JJ 86, no. 308-309, fol. 102v-103, ed. Luce, no. 28-29; AN JJ 86, no. 320, fol. 107; AN JJ 86, no. 392, fol. 136; AN JJ 86, no. 596, fol. 217, ed. Luce, Histoire, no. 41; AN JJ 90, no. 292, fol. 149v-50r, ed. Luce, Histoire, no. 46.

${ }^{30}$ The cost of a remission in the fourteenth century was not supposed to be more than 32 sous de Paris, equivalent to about 100 days' pay for an unskilled worker (Gauvard, "De grâce especial”, 1:68, but see her n. 32 for other data). Yves-Bernard Brissaud, "Le droit de grâce à la fin du moyen-âge 
(XIV $-\mathrm{XV}^{\mathrm{e}}$ siècles). Contribution à l'étude de la restauration de la souveraineté monarchique," Unpublished doctoral dissertation, Université de Poitiers, Faculté de droit et des sciences sociales (Poitiers, 1971), 246 estimated 60 sous for the notaries alone. It was possible to receive a remission for free (sine financia), but none of the remissions in this corpus bears that mention. On the procedure in this period, see Les ordonnances des rois de France de la troisième race..., ed. Eusèbe de Laurière, Denis-François Secousse, et al., 21 vols. and supplément (Paris, 1723-1849), 3:219-32 at art. 11, 12, pp. 226-27 and 3:385-89, at art. 21, p. 388 and Brissaud, "Le droit de grâce," 226-31, 240-50, 464-538.

${ }^{31}$ Five remissions mention Calle by name: AN JJ 86, no. 365, fol. 124v-25r, ed. in Luce, Histoire, no. 35, AN JJ 86, no. 387, fol. 133v-34r, ed. Luce, Histoire, no. 37, AN JJ 86, no. 391, fol. 136r, AN JJ 86, no. 392, fol. 136, AN JJ 98, no. 252, fol. 80, ed. Luce, Histoire, no. 63. Calle is also named in Jean de Venette, Chronique, ed. Beaune; Chronique des règnes de Jean II et Charles V, ed. Delachenal; and Chronique des quatre premiers Valois, ed. Luce. See also AN JJ 86, no. 606, fol. 223v-24r and AN JJ 94, no. 4, fol. 3v, ed. Luce, Histoire, no. 61

${ }^{32}$ E.g. AN X1a 19, fol. 348v-50r; AN JJ 86, no. 231, fol. 75v-76r, ed. Luce, no. 30; AN JJ 86, no. 207, fol. 67v, ed. Luce. no. 25. Cohn, "Enigmas of Communication", 232-35.

${ }^{33}$ One remission relates that those who acted "comme Capitaine, faiseur, conseilleur \& complice" were considered especially guilty (AN JJ 86, no. 207, fol. 67v, ed. in Luce, Histoire, no. 25).

${ }^{34}$ AN X1c 13b, nos. 272-73.

35 AN JJ 86, no. 309, fol. 103, ed. Luce, Histoire, no. 29. See also AN X1a 19, fol. 191v-92r for Drieu de Villemaistrie, actor principalis in the destruction of a manor, who was thought potentially capable of paying 4,000 livres parisis in civil damages.

${ }^{36}$ AN JJ 86, nos. 391-92, fol. 136.

${ }^{37}$ AN JJ 86, no. 153, fol. 51v and AN JJ 86, no. 365, fol. 124v-25r; AN JJ 90, no. 556, fol. 275v76 r. 
${ }^{38}$ Rose's multiple children suggests that he was at least in his mid-20s. We have information about the age only of one Jacques, Arnoul Génelon, who must have been about 30 at the time of the revolt, for in 1398 he described himself as "agie de soixante dix ans ou environ" in a donation to the monks of Saint-Maurice of Senlis (Beauvais, Archives départmentales de l'Oise [hereafter AD Oise] H 841). Arnoul was married at some point before 1387 to a woman named Genviève (ibid.). ${ }^{39}$ AN JJ 90, no. 476, fol. 238v-39r, ed. Luce, Histoire, no. 52. There was no detectable participation by nobles in the Jacquerie, except for the Countess of Valois, who was under duress when she laid out food and drink for the rebels (Chronique des quatre premiers Valois, ed. Luce, 72).

${ }^{40}$ AN JJ 86, no. 365, fol. 124v-25r, ed. Luce, Histoire, no. 35; AN JJ 88, no. 1, fol. 1-2r (erroneously cited in Luce, Histoire, 177 as AN JJ 87, no. 1).

${ }^{41}$ Chronique des quatre premiers Valois, ed. Luce, 71-72. "le dit general capitaine du dit plat pais [here explicitly identified as Calle] envoya ycelui Jehan \& un autre comme contrains porter lettres au bourgois et habitanz dicelle ville de Compiegne afin qu'il vousissent estre aliez avec les genz du dit plat pais" (AN JJ 86, no. 365, fol. 124v-25r, partly ed. Luce, Histoire, no. 35); "Johannus Orrcet cupiens pro posse suo dictos domicellos a morte liberari de consensu predicti capitanei Sancte Maxencie magno capitaneo dictorum innobilium scripsisset ut super hoc providere vellet" (AN JJ 94, no. 4 , fol. 3r).

${ }^{42}$ Charles du Fresne du Cange, Glossarium mediae et infimae latinitatis, 10 vols. (Graz, 1954 [1678]), 4:275, vid. Iacobi, which quotes Register 3, fol. 218 of the Memorials of the Chambre de Comptes: "Sigillum Capitanei Rusticorum vocatorum Jacoborum decapitate apud Claromontem in Belvacino, fuit traditum Camerae per Thomam Brochardi Receptorm Silvanect. 11 Dec 1356 (sic)." While the document itself, which would later have been called Memorial C, does not seem to have survived the fire of 1737 that destroyed most of the Chambre's archives, the effort to reconstruct those memorials does contain a patent letter from December 1358, formerly in Memorial C, fol. 218, regarding confiscations and forfeitures for lèse-majesté and other crimes 
(AN P 2293, pp. 163-64). The sentence noted by Du Cange may have been part of a list of confiscations that the eighteenth-century clerk did not consider worth transcribing.

${ }^{43}$ Quote at AN X1a 19, fol. 410r. See also AN X1c 11, nos. 61-62 and AN X1c 32a, no. 31.

44 "novisque auditis de certis ordinationibus perpositi mercatorum Parisiensis apud Gonesse missis per habitantes predictos fuerat ordinatum ut predicti capitaneus \& Philipus eius consiliarius apud Gonesse accedere pro dictis ordinationibus audiendis. Antequam vero illuc accederent proclamari fecerat ... quod nullus obedirent preposito dicte ville, justiciam seu jurisdictionem eiusdem nomine regis regentis tamquam contentionsam inter procuratorem regis et religiosas de Malodunio, nec quod curatus ville esset ausus aliquid contra habitantes predictos sigillare" (AN X1a 19, fol. 348v$50 \mathrm{r})$.

${ }^{45}$ AN JJ 86, no. 309, fol. 103, ed. Luce, Histoire, no. 29.

${ }^{46}$ AD Oise H 2439, no. 4. Although he was living near Pont-Sainte-Maxence at the time of the revolt, Germain's surname indicates a family origin in a village very near the servile settlements that revolted against the cathedral chapter of Laon in 1338 (Ghislain Brunel, "Les hommes de corps du chapitre cathedral de Laon (1200-1460): Continuité et crises de la servitude dans une seigneurie ecclésiastique," in Forms of Servitude in Northerm and Central Europe: Decline, Resistance, and Expansion, ed. Paul Freedman and Monique Bourin (Turnhout, 2005), 131-77).

${ }^{47}$ AN JJ 86, no. 596, fol. 217, ed. Luce, no. 41.

48 "bien \& loyaument porter en la compaignie des bien vuillanz de nostre dit seigneur de nous \& de la couronne de France contre noz ennemis" (AN JJ 90, no. 288, fol. 148r, ed. Luce, Histoire, no. 24; AN JJ 90, no. 294, fol. 150, ed. Luce, Histoire, no. 48).

${ }^{49}$ AN JJ 90, no. 148, fol. 79v-80r (ed. Ghislain Brunel, "Archives de la révolte et lettres de rémission: des serfs du Laonnois (1338) aux Jacques de Picardie (1358)," in La Jacquerie: Entre mémoire et oubli, 1358-1958-2008, ed. Pierre Rigault and Patrick Toussaint (Amiens, 2012), 71-72). 50 "Symon de Berne, prevost de Beaumont sur Aise et capitaine de la conte de Beaumont" (AN JJ 86, no. 207, fol. 67v, ed. Luce, Histoire, no. 25). 
${ }^{51}$ Brigitte Bedos, La châtellenie de Montmorency des origines à 1368 (Pontoise, 1980), 172.

${ }^{52}$ [Reference to author's forthcoming book], ch. 4.

${ }^{53}$ Amiens: Chronique normande, ed. Molinier and Molinier, 129; Chronographia, ed. Moranvillé, 2:272; JJ 86, no. 239, fol. 78v-79r, ed. Denis-François Secousse, Receuil des pièces servant des preuves sur les troubles excités en France par Charles II dit le mauvais, roi de Navarre et comte d'Evreux (Paris, 1755), 97-99. Senlis: Jean de Venette, Chronique, ed. Beaune, 180-83; Chronique des règnes, ed. Delachenal, 1:17778; AN JJ 86, no. 421, fol. 147, ed. Luce, Histoire, no. 43; AN X1a 21, fol. 514; AN X1a 22, fol.47r. Jaux: AN JJ 86, nos. 361-62, fol. 123r. Montataire: AN JJ 98, no. 252, fol. 80, ed. Luce, Histoire, no. 63.

${ }^{54}$ AN JJ 86, no. 344, fol. 116v-17r; AN JJ 90, no. 294, fol. 150, ed. Luce, Histoire, no. 48; AN JJ 90, no. 556, fol. 275v-76r; AN JJ 90, no. 476, fol. 238v-39r, ed. Luce, Histoire, no. 52.

${ }^{55}$ Jacques Sabbe, Vlaanderen in Opstand, 1323-1328: Nikolaas Zannekin, Zeger Janszone en Willem de Deken (Bruges, 1992); William H. TeBrake, A Plague of Insurrection: Popular Politics and Peasant Revolt in Flanders, 1323-1328 (Philadelphia, 1993); A. Butcher, "English Urban Society and the Revolt of 1381” and R. B. Dobson, "The Risings in York, Beverley and Scarborough" in The English Rising of 1381, ed. R. H. Hilton and T. H. Aston (Cambridge, 1984), 84-111, 112-42; Vincent Challet, "Le Tuchinat en Toulousain et dans le Rouergue (1381-1393): d'une émeute urbaine à une guérilla rurale?," Annales du Midi, 118 (2006): 513-25. The Auvergnat Tuchins, active from the 1360s through the 1380s, were more rural in character but still had important relations with agglomerations like Saint-Flour and Brioude: Pierre Charbonnier, "Qui furent les Tuchins," Violence et contestation au moyen âge, Actes du $114^{\circ}$ Congrès national des sociétés savantes (Paris, 1989) (Paris, 1990), 235-47.

${ }^{56}$ Comparatively, see the appendices of biographies in TeBrake, Plague of Insurrection and in Chris Dyer, "The Rising of 1381 in Suffolk: Its Origins and Participants," Proceedings of the Suffolk Institute of Archaeology and History, 36 (1988): 274-87, esp. comments at 276. 
57 "gens de labour le plus, et si y avoit de riches hommes, bourgois et autres" (Chronique des règnes de Jean II et Charles V, ed. Delachenal, 1:180).

58 “ex parte Colini Tonsoris, de Balleyo, clerici” (AN JJ 86, no. 465, fol. 164, ed. Luce, Histoire, no. 40). Tonsoratus or tonsuratus is the word for "tonsured."

${ }^{59}$ Firnhaber-Baker, "À son de cloche," 368-70.

${ }^{60}$ Aiton, “'Shame,” 203.

${ }^{61}$ Philippe Contamine, Guerre, État et société à la fin du Moyen Âge: Études sur les armées des rois de France, 1337-1494, 2 vols. (Paris, 1972), 1:35-38, 53-56; Xavier Hélary, L'armée du roi de france: La guerre de Saint Louis à Philippe le Bel (Paris, 2012), 56-60; TeBrake, Plague of Insurrection; Christ Dyer, "The English Medieval Village Community and its Decline," Journal of British Studies, 33 (1994): 407-29, esp. 416-18; Montgomery Bohna, "Armed Force and Civic Legitimacy in Jack Cade's Revolt, 1450", The English Historical Review, 118 (2003): 563-82; Andy Wood, "Collective Violence, Social Drama and Rituals of Rebellion in Late Medieval and Early Modern England" in Cultures of Violence: Interpersonal Violence in Historical Perspective, ed. Stewart Carroll (Basingstoke and New York, 2007), $101-14$

62 "dizinier dessoubzle Capitaine de la dite ville de Jaux et s'eust alez par contrainte avec pluseurs de la ville \& autres du plat pais aus commotions" (AN JJ 86, no. 362, fol. 123).

${ }^{63}$ Such assemblies and the political culture that lay behind them have been discussed at length. Among others, see Peter Bierbrauer, "Der Aufsteig der Gemeinde und die Entfeudalisierung der Gesellschaft im späten Mittelalter," in Kommunalisierung und Christianisierung: Voraussetzungen und Folgen der Reformation, 1400-1600, ed. Peter Blickle and Johannes Kunisch (Zeitschrift für Historische Forschung, 9, Berlin, 1989), 29-55; Peter Blickle (ed.), Resistance, Representation, and Community (Oxford, 1997); Susan Reynolds, Kingdoms and Communities in Western Europe, 900-1300, 2nd edn., (Oxford, 1997). On assemblies, mobilization, and political culture in the Jacquerie's heartlands, see Justine Firnahber-Baker, “The Monks and the Masses at Saint-Leu d'Esserent: Rural Politics 
in Northern France before the Jacquerie," in The Routledge History Handbook of Medieval Rural Life, ed. Miriam Müller (Abingdon and New York, forthcoming 2019).

${ }^{64}$ Saint-Vrain: AN JJ 86, no. 265, fol. 89r, ed. Luce, Histoire, no. 34; AN JJ 86, no. 465, fol. 164, ed. Luce, Histoire, no. 40; AN JJ 86, no. 578, fol. 209v-10r, confirmed at AN JJ 95, no. 116, fol. 44v; AN JJ 86, no. 596, fol. 217, ed. Luce, Histoire, no. 41. Goyencourt and Breteuil: AN JJ 88, no. 89, fol. 56v-57r; AN JJ 90, no. 476, fol. 238v-39r, ed. Luce, Histoire, no. 52 and AN JJ 90, no. 496, fol. 247v-48r. Picardy: AN JJ 88, no. 89, fol. 56v-57r. South of Paris: AN JJ 86, no. 231, fol. 75v76r, ed. Luce, Histoire, no. 30. "les habitans de la ville de Blacey en la prevoste de Vitry aient este ou envoie certaines personnes avec les habitans de plusieurs autres ville du pays de Champaigne a plusieurs assamblees" (AN JJ 95, no. 22, fol. 10v-11r; similar language for Heiltz-le-Marrupt at AN JJ 86, no. 357, fol. 122, ed. Luce, Histoire, no. 31 and see AN JJ 86, no. 596, fol. 217, ed. Luce, Histoire no. 41 for Chavanges). On the role of assemblies in facilitating inter-village and regional communication and organization in the Jacquerie, see Cohn, "Enigmas of Communication," 23335.

65 "Jehan Bridoul, Thomas des Croutes autrement dit des Prez, Odin Louys, Colin Paste, Guillot Fauvel, Jehan Rogier, touz de Turcy, Colet Michon, Colet Hemon, Colet Vital, Guillot Lestre, Raoulet Cormorin, Jehannot Pillet, Jehannot Driart \& Perrinet le Forestier, touz de Lussis" (AN JJ 86, no. 269, fol. 90).

${ }^{66}$ AN JJ 100, no. 478, fol. 148r.

${ }^{67}$ AN JJ 145, no. 498, fol. 229v-30r.

68 "grant nombre de gens du plat pais vindrent en la dite ville et par contrainte furent avec eulz a faire les diz malefices" (AN X1c 11, nos. 61-62).

${ }^{69}$ AN X1c 32a, no. 31.

${ }^{70}$ On the kinds of intramural tensions that could generally afflict villages, see Dyer, "English Medieval Village," 418-24. 
${ }^{71}$ Gonesse: AN X1a 14, fol. 476-77, ed. Luce, Histoire, no. 57. Ermenonville: Chronique normande, ed. Molinier and Molinier, 130.

72 "coururent ... mesme sur leurs seigneurs" (Chronique normande, ed. Molinier and Molinier, 128); Autrand, Charles V, 328; Firnhaber-Baker, "Eponymous Jacquerie," 66-67.

${ }^{73}$ The status of nobility is often casually conflated with the possession of lordship in current writing, but they were distinct attributes. For example, a knight was certainly noble but might not hold any estate over which he exercised the fiscal and jurisdictional rights and responsibilities of lordship. A count's daughter was noble at birth, but she would only become a lord if she came into seigneurial lands through inheritance or dower. Noble status was becoming increasingly detached from lordship in late medieval France. See Philippe Contamine, La Noblesse au royaume de France de Philippe le Bel à Louis XII: Essai de synthèse (Paris, 1997), esp. 85-133.

74 “subgez \& justicables de nostre ame \& feal messire Gobert de la Bonne chevalier seigneur dudit lieu et aussi Guillaume Mansone, homme de corps du dit chevalier” (AN JJ 86, no. 377, fol. 129r). Serfdom had become rare in the Francilien and Picard heartlands of the Jacquerie, but it persisted more commonly in Champagne, whence hailed this bome de corps. The other instances are at Le Limon near Meaux (AN JJ 86, unnumbered entry, fol. 111r for a cobbler, homme de corps) and Châlons-en-Champagne, $\mathrm{AD}$ de la Marne $\mathrm{H}$ 82, in which the 44 village representatives of Dompremy are said to be the hommes or femmes de corps of different individuals or institutions, though these people claimed not to have actually participated in the revolt.

75 "faire commandement de par nostre dit seigneur \& de par nous" (AN JJ 90, no. 148, fol. 79v80r, ed. Brunel, 'Des serfs du Laonnois', 71-72); Chronique des quatre premiers Valois, ed. Luce, 74 76 “interrogavit eos qualem potestatem ispi ad hoc habebant \& an illud de nostra licencia vel mandato aut aliter faciebant" (AN JJ 86, no. 606, fol. 223v-24r).

77 “envoierent a Compiegne par devers le bailli de Senliz pour savoir se il savoit a quelle cause le dit capitaine faisoit tiex mandemenz" (AN JJ 90, no. 354, fol. 182, ed. Luce, Histoire, no. 49). 
78 “tels congregacions \& assemblees \& faire capitaine de pais ou Royaume de France senz l'auctorité \& licence de nostre dit seigneur ou de nous ne se pouvoie[nt] bonnement faire" (AN JJ 86, no. 392, fol. 136).

79 "les quiex habitanz firent pluseurs maux en la presence du dit Jaquin, qui touz jours leur disoit: Ne boutez nulz feux; et, pour les plus tost faire cesesr, leur disoit: Attendez à une autre foiz; et pour ce l'appelloient traytre, et li vouloient couper la teste" (AN JJ 86, no. 207, fol. 67v, partially ed. in Luce, Histoire, no. 25).

80 "la grant orreur quil avoit des exces \& oultrages que les dites gens du plat pais faisoit contre son gre et ou il ne povoit mettre remede" (AN JJ 90, no. 288, fol. 148r, ed. Luce, Histoire, no. 24). See also AN JJ 90, no. 354, fol. 182, ed. Luce, Histoire, no. 49, among others.

81 “crierent les Jacques que jà ne fuiront et qu'ilz sont assez fors pour combater les gentilz hommes" (Chronique des quatre premiers Valois, ed. Luce, 73).

${ }^{82}$ There are over 50 non-noble women in the source corpus, but I have excluded those who were not the object of legal pursuit or of Counter-Jacquerie retribution. My count also excludes the borderline case of 10 servile women listed among the village representatives who agreed to the imposition of a seigneurial oven in Dompremy in gratitude for their monastic lords' protection during the Counter-Jacquerie ( $\mathrm{AD}$ de la Marne $\mathrm{H}$ 82) because the women's relationship to the revolt seems too indirect to count them alongside other, more clearly connected women, especially since the villagers claimed innocence.

${ }^{83}$ e.g. "les gens du plat pais nommez Jaques" (AN JJ 87, no. 117, fol. 80v-81r and AN JJ 90, no. 488, fol. 244r, ed. Luce, Histoire, no. 50). See below, n. 100.

${ }^{84}$ Cohn, Lust for Liberty, 130-35; idem, "Women in Revolt in Medieval and Early Modern Europe," in The Routledge History Handbook of Medieval Revolt, ed. Justine Firnhaber-Baker with Dirk Schoenaers (Abingdon and New York, 2017), 208-19, at 210-11. 
${ }^{85}$ Vincent Challet, "Un village sans histoire? La communauté de Villeveyrac en Languedoc," in The Voices of the People in Late Medieval Europe: Communication and Popular Politics, ed. Jan Dumolyn, Jelle Haemers, H. Rafael Oliva Herrer, and Vincent Challet (Turnhout, 2014), 123-38, at 133. ${ }^{86}$ Women on Top" in Society and Culture in Early Modern France (Stanford, 1975), 146. Davis argued that differential prosecution meant that early modern women were actually freer than men to engaging in rioting, a different phenomenon than the kind of large-scale revolt considered here. Even if the (hypothetical) effects of more lenient prosecution meant that medieval French women also felt at similar liberty to revolt (a proposition on which I make no judgment), this does not obviate the point that we would see them less in the kinds of criminal sources that provide the vast majority of data for the Jacquerie's constituents as opposed to the much wider variety of sources that record early modern uprisings (see the studies referenced in Davis, “Women on Top", 314, nn. 38-39).

${ }^{87}$ E.g., while witchcraft prosecutions were increasing aimed at women especially in Alpine communities after c. 1400 (Mark Bailey, "The Feminization of Magic and the Emerging Ideal of the Female Witch in the Late Middle Ages," Essays in Medieval Studies, 19 (2002): 120-34), women were punished more leniently than men for bigamy in fifteenth-century Champagne (Sara McDougall, Bigamy and Christian Identity in Late Medieval Champagne (Philadelphia, 2012), 49-74).

${ }^{88}$ Jelle Haemers and Chanelle Delameillieure, "Women and Contentious Speech in FifteenthCentury Brabant," Continuity and Change, 32 (2017): 323-47, at 325. Haemers and Delameillieure show that women were criminally prosecuted for "verbal violence," a female case of which Cohn has also noted in Douai ("Women in Revolt," 209, 216).

${ }^{89}$ Sylvia Federico, “The Imaginary Society: Women in 1381," Journal of British Studies, 40 (2001): 159-83, at 159.

90 ibid., 182.

${ }^{91}$ Jeanne Doucet, widow of Eudes Doucet and wife of Jean Petit (appearing as a defendant in AN X1a 31, fol. 253 and as a witness in AN X1a 28, fol. 175v-76r); Perrote, wife of the late Thomas 
Harare (AN X1c 13b, no. 255); the widows of Denisot Guigaut and of Jean de Bergny, now married to Pasquier and Henry Barat, both themselves accused Jacques (AN X1c 32a, no. 30-31); Jacquette, daughter of the late Jean de Aucart (AN X1a 19, fol. 407v).

92 "lequel defunct en son vivant \& sa dicte femme estoient communis en biens, et apres la mort dicellui feu avoit ycelle femme prinz la moitie de biens qui leur avoient este communis durant leur dit marriage \& party aux heritages dudit defunct tant en biens meubles comme en debtes \& en acquestes ... durant leur dit marriage prinz desdiz biens dudit feu chevalier \& enrichy diceux de la valeur de iic livres et plus... en estoient enrichiz yceux feu Jehan de Bergny \& la dite femme dudit Henry lors sa femme de la somme de viiixx livres Paris \& plus" (AN X1c 32a, no. 31). The court of the Requests ultimately absolved the defendants, but not because they were innocent.

${ }^{93}$ AN X2a 7, fol. 213r. See above, n. 23 on criminal prosecution and this case.

${ }^{94}$ AN X1c 13b, no. 255.

${ }^{95}$ AN JJ 86, no. 326, fol. 109v

${ }^{96}$ AN X1a 23, fol. 491v-93r.

${ }^{97}$ AN X1c 13a, nos. 56-57.

98 “raptu Tassone quondam uxoris Massi de Veris prope Latigniacum” (AN JJ 91, no. 333, fol. $173 \mathrm{v})$

99 “Imaginary Society," 164.

${ }^{100}$ Dijon, AD du Côte d’Or B 1451, fol. 85v; AN JJ 86, no. 430, fol. 151r; AN JJ 87, no. 117, fol. 80v-81r; AN JJ 87, no. 321, fol. 204v-205, ed. Luce, Histoire, no. 45; AN JJ 88, no. 9, fol. 7r; AN JJ 90, no. 354, fol. 182, ed. Luce, Histoire, no. 49; AN JJ 90, no. 488, fol. 244r, ed. Luce, Histoire, no. 50; AN JJ 89, no. 377, fol. 159; AN JJ 145, no. 498, fol. 229v-30r; AN X1c 32a, no. 31. Use as a term of abuse but not definitely connected to personal participation in the revolt of 1358 at $\mathrm{AN}$ JJ 156, no. 397, fol. 241 and AN X1c 15b, no. 151. For contemporary explanations of the origin of the term, see below, n. 103.

${ }^{101}$ Federico, 'Imaginary Society', 183. 
${ }^{102}$ Firnhaber-Baker, "Eponymous Jacquerie," 60-62. On the arrière-ban in this period, Contamine, Guerre, État et société, 35-36 and Les ordonnances, ed. de Laurière, Secousse, et al., 3:34, art. 26 and 3:138, art. 32 .

${ }^{103}$ Jean de Venette, Chronique, ed. Beaune, 144 and Chronique normande, ed. Molinier and Molinier, 129.

${ }^{104}$ James E. Gilbert, “A Medieval 'Rosie the Riveter'? Women in France and Southern England during the Hundred Years War," in The Hundred Years War: A Wider Focus, ed. L. J. Andrew Villalon and Donald J. Kagay (Leiden, 2005), 333-63. Other pertinent examples include the "noblewomen, men's wives, and little girls" of Toulouse who worked the mangonel that killed Simon de Montfort in 1218 (The Song of the Cathar Wars: A History of the Albigensian Crusade, ed. and trans. Janet Shirley (Farnham, 2000), liasse 25, p. 172) and the female standard bearer who served the Flemish rebel captain Peter Van den Bossche, killed in battle with the French just prior to the Battle of Roosebeke in 1382 (Sumption, Hundred Years War, 3:482).

${ }^{105}$ Chronique des quatre premiers Valois, ed. Luce, 72.

106 "Posuerunt iterum mulieres ad fenestras, ut super eos aquas bullientes abundanter effunderent" (Jean de Venette, Chronique, ed. Beaune, 180).

${ }^{107}$ On English rural women, see among others, R. H. Hilton, "Women in the Village,", in The English Peasantry in the Later Middle Ages: The Ford Lectures for 1973 and Related Studies (Oxford, 1975), 95-110; Judith Bennett, Women in the Medieval English Countryside: Gender and Household in Brigstock before the Plague (Oxford, 1987); Sherri Olson, A Mute Gospel: The People and Culture of the Medieval English Common Fields (Toronto, 2009); eadem, “Women's Place and Women's Space in the Medieval Village," in Rural Space in the Middle Ages and Early Modern Age: The Spatial Turn in Premodern Studies, ed. Albrecht Classen with Christopher R. Clason (Berlin and Boston, 2012), 209-25; and Maryanne Kowaleski, "Gendering Demographic Change in the Middle Ages," in The Oxford Handbook of Women and Gender in Medieval Europe, ed. Judith Bennett and Ruth Mazo Karras (Oxford, 2013), 181-92. 
${ }^{108}$ AD Oise Hs 664; AD de la Marne H 82.

${ }^{109}$ Robert Fossier, Peasant Life in the Medieval West, trans. Juliet Vale (Oxford, 1988).

${ }^{110}$ AN X1c 13b, no. 255; AN X1c 32a, no. 31 and above n. 91.

111 "bona reperta rapiebant, se ipsos et feminas/uxores suas rusticanas curiosius vestientes" (Jean de Venette, Chronique, ed. Beaune, 176 with variant).

112 "Il se livrèrent au pillage; eux et leurs femmes revêtirent avec une curiosité indue l'habit des nobles" (Jean de Venette, Chronique, ed. and trans. into French, Beaune, 177); "carried off such property as they found, wherewith they clothed themselves and their peasant wives luxuriously" (Jean de Venette, The Chronicle of Jean de Venette, trans. J. Birdsall, New York, 1953), 77).

${ }^{113}$ AN X1a 23, fol. 491v-93r, quote at fol. 492r.

${ }^{114}$ AN X1c 32a, no. 31.

${ }^{115}$ For example, see Jean de Venette's critique of nobles' excessively luxurious and revealing clothes (Chronique, ed. Beaune, 74, 142-44) and the royal chronicler's account of Étienne Marcel trading his red-and-blue hood for the Dauphin's fur hat after killing the prince's councilors (Chronique des règnes de Jean II et Charles V, ed. Delachenal, 2:149-50).

${ }^{116}$ For French laws and clothing as "an expressive communicative device," see Sarah-Grace Heller, "Anxiety, Hierarchy, and Appearance in Thirteenth-Century Sumptuary Laws and the Roman de la rose," French Historical Studies, 27 (2004): 311-48, quote at 330. On visual and sartorial signalling of social discontent, see Christian de Merindol, 'Mouvements sociaux et troubles politiques à la fin du Moyen Âge: Essai sur la symbolique des villes', Actes du 114e Congrès national des societies savants (Paris, 1989) (Paris, 1990), 267-302. On ludic and performative aspects of protest, including through clothing, see Natalie Zemon Davis, "The Reasons of Misrule" and "Women on Top" in Society and Culture in Early Modern France (Stanford, 1975), 97-151.

${ }^{117}$ For wearing the Parisian hoods as a crime, see AN JJ 86, no. 214, fol. 69v-70r; AN JJ 86, no. 238, fol. 78; AN JJ 86, no. 266, fol. 89; AN JJ 86, no. 282, fol. 94; and AN JJ 86, no. 390, fol. 135, among others. Noble hoods: "pendu à sa sainture souz son mantel un chapon my parti, par quoy 
il cuidièrent estre trahis, \& qu'il fuissent des espies des gentils hommes" (AN JJ 96, no. 425, fol. 145, ed. Luce, Histoire, no. 62). Charles of Navarre's partisans wore “chaperons de sa livree de drap vert \& camelin" (AN JJ 86, no. 266, fol. 89).

${ }^{118}$ Vincent Challet, "Violence as a Political Language: The Uses and Misuses of Violence in Late Medieval French and English Popular Rebellions," in The Routledge History Handbook of Medieval Revolt, ed. Justine Firnhaber-Baker with Dirk Schoenaers (Abingdon and New York, 2017), 27991 , at $287-88$ ${ }^{119}$ Above, n. 3.

${ }^{120}$ On acts of resistance short of (or different to) armed revolt, see James C. Scott, Weapons of the Weak: Everyday Forms of Peasant Resistance (New Haven, 1986) and idem, Domination and the Arts of Resistance: Hidden Transcripts (New Haven, 1990). Chris Wickham, "Gossip and Resistance among the Medieval Peasantry," Past and Present 160 (1994): 3-24, esp. 15-16 applies Scott's insights to a medieval activity often perceived as feminine. See also Haemers and Delameillieure, "Women and Contentious Speech,” 326.

${ }^{121}$ Firnhaber-Baker, "Eponymous Jacquerie.”

${ }^{122}$ Charles Tilly, The Politics of Collective Violence (Cambridge, 2003), 110. 